\title{
Developing the prototype AndaLAND for agriculture soil and water assessment in climate change scenarios
}

\author{
Desarrollo del prototipo AndaLAND para evaluar suelos agrícolas y agua en el marco del \\ cambio climático \\ Desenvolvimento do protótipo AndaLAND para avaliação de solos agrícolas e da água em \\ cenários de alterações climáticas
}

\section{AUTHORS}

\section{Fernández-Boyano}

M. ${ }^{\circledR, 1}$

marta.fernandez@

inclam.com

\section{Tabernero-Pérez \\ D. ${ }^{1}$}

\section{Alonso-Herrero S. \\ Pérez-Álvarez J. \\ M. ${ }^{2}$ \\ Blanco-Velázquez \\ F.J. ${ }^{2}$}

Anaya-Romero M. ${ }^{2}$

\section{Fernández-Luque J. E. ${ }^{3}$}

@ Corresponding Author ${ }^{1}$ INCLAM, S.A. Calle Samaria, 4. 28009 Madrid, Spain.

${ }^{2}$ EVENOR-TECH, S.L.U. "Soluciones para uso y protección del suelo". C/ Naos, 7, 2 Dcha. 41011 Sevilla, Spain.

${ }^{3}$ Instituto de Recursos Naturales y Agrobiología de Sevilla (IRNAS-

CSIC). Avenida Reina Mercedes 10. 41080 Sevilla, Spain.
Received: 30.10.2015 | Revised: 27.01.2016 | Accepted: 16.02.2016

\section{ABSTRACT}

There is a critical need to incorporate concerns on soil and water use and protection into land use planning policies and practices, not exclusively in protected areas, especially taking into account the widespread power transfer to local authorities regarding land-use decision making. Accordingly, it is extremely useful what Decision Support Systems (DSS) do on land use. AndaLAND is a prototype DSS which has been developed as a web-based application. It helps to define the vulnerability and the efficiency of the use and protection of soils in the selected target region: Andalusia (Southern Spain). AndaLAND integrates a complete catalogue of information on climate, soil and soil management, to make land vulnerability evaluation. By using Web Map Services (WMS), AndaLAND is fed with available databases from public mapping services (the Geographic Information System for the Common Agricultural Policy-SIGPAC) and other external sources (Microcomputed-based Land Evaluation Information System, MicroLEIS). Climate change scenarios are considered jointly with other relevant global change elements, such as land use change. Soil evaluation is based on decision rules that follow a decision tree. This method was established from Drools (a powerful hybrid reasoning system), using agrological rules for determining soil capacity in plots. The tool is capable of evaluating individually more than 6 million plots currently existing in the Andalusian region. AndaLAND's final output is a report on the particular vulnerability of a user-specified plot. The report includes information on the plot's geographical location, its environmental status regarding to (current and potential) impacts, degradation and/or pollution in the water-soil-crop system and eventual affections due to climate change-induced events. The report also provides practical recommendations for sustainable use and management of plots (in particular, for irrigated crops, these recommendations are linked to available irrigation technologies and water consumption).

\section{RESUMEN}

Cada vez se hace más patente la necesidad de implementar politicas y prácticas de planificación territorial que integren criterios para la protección del uso del suelo y el agua, no sólo en las zonas naturales protegidas, y considerando a su vez el papel desempeñado por las administraciones locales y pequeños agricultores en la toma de decisiones sobre los distintos usos del suelo. Por ello, y dado que existe una práctica cada vez más generalizada en el uso de Sistemas de Ayuda a la Decisión (SAD) para la gestión de los usos del suelo, AndaLAND se presenta como un prototipo de $S A D$ desarrollado como una aplicación web. Esta herramienta permite determinar la vulnerabilidad y la eficiencia en el uso y protección de los suelos en la región objetivo de estudio: Andalucía (S España). AndaLAND integra un catálogo muy completo sobre información climática, de suelos y de manejo de los mismos, para poder realizar la 
evaluación de la vulnerabilidad de suelos objetivo. Mediante el uso de Web Map Services (WMS), AndaLAND es capaz de volcar la información procedente de las bases de datos de servicios de cartografía públicos (el Sistema de Información Geográfica de la Politica Agraria Común-SIGPAC), asi como otras fuentes muy diversas (sistemas de información de evaluación de suelos ya existentes en servicios web, MicroLEIS). Los escenarios de cambio climático están incorporados como información relevante para poder predecir los posibles impactos asociados a los cambios de uso del suelo. La evaluación global del suelo se establece a partir de reglas definidas mediante árboles de decisión. Dicho método fue implementado a través del sistema Drools (sistema de gestión de reglas), utilizando criterios agronómicos para determinar la capacidad agrológica en las parcelas. De esta forma, la herramienta es capaz de evaluar individualmente más de 6 millones de explotaciones declaradas actualmente en Andalucía. El resultado final del uso de AndaLAND es un informe individual sobre la vulnerabilidad de la parcela objetivo definida por el usuario. Dicha documentación incluye información sobre la localización geográfica de la parcela, su estado medioambiental con respecto a actuales y potenciales impactos, la posible fase de degradación y/o contaminación en el sistema suelo-agua-cultivo, y la probabilidad de verse afectada por los efectos asociados al cambio climático. El informe final incorpora recomendaciones prácticas para el uso y gestión sostenible en la parcela objetivo (en particular, en el caso de cultivos de regadio estas pautas están referidas a tecnologías de riego existentes y hacia el consumo de agua).

\section{RESUMO}

Cada vez é mais evidente a necessidade de implementar politicas e práticas que integrem critérios de ordenamento do território para a proteção do uso do solo e da água, não só nas áreas protegidas, tendo em consideração o papel das autoridades locais e dos pequenos agricultores na tomada de decisão sobre os diversos usos do solo. Por isso, e uma vez que existe uma prática cada vez mais difundida no uso de Sistemas de Apoio à Decisão (SAD) para a gestão do uso do solo, o AndaLAND é apresentado como um protótipo dos SAD desenvolvido como uma aplicação web. Esta ferramenta permite determinar a vulnerabilidade e eficiência no uso e proteção do solo na área de estudo: Andaluzia (Sul de Espanha). O AndaLAND integra um catálogo abrangente de informações sobre o clima, solo e gestão da mesma, para permitir a avaliação da vulnerabilidade dos solos alvo. Usando serviços Web Map (WMS), - AndaLAND permite descarregar as informaçôes dos bancos de dados de mapeamento de serviços públicos (Sistema de Informação Geográfica para a Politica Agricola Comum-SIGPAC) assim como de outras fontes diversas (sistemas de informação para a avaliação de serviços web do solo existentes MicroLEIS). Os cenários de alteraçôes climáticas são construídos como informação relevante para prever os potenciais impactos associados com as mudanças no uso do solo. A avaliação global do solo é estabelecida a partir de regras definidas usando árvores de decisão. Este método foi implementado através do sistema Drools (sistema de regras de gestão), utilizando critérios agronómicos para determinar a capacidade agrológica das parcelas. Assim, esta ferramenta é capaz de avaliar individualmente mais de 6 milhóes de exploraçôes atualmente existentes na Andaluzia. O resultado final do uso AndaLAND é um relatório individual sobre a vulnerabilidade da parcela definida pelo utilizador como parcela-alvo. Esta documentação inclui informaçôes sobre a localização geográfica da parcela, o seu estado ambiental em relação a atuais e potenciais impactos, possivel fase de degradação e l ou contaminação no sistema solo-água-cultura e a probabilidade de ser afetada pelos efeitos associados às alteraçôes climáticas. O relatório final inclui recomendações práticas para a utilização e gestão sustentável na parcela-alvo (especialmente no caso das culturas de regadio estas orientaçôes referem-se às tecnologias de rega existentes e ao consumo de água). 


\section{Introduction}

The relevance of soils and soil cover to crucial aspects for human life (food production, hydrological cycles, air composition) will progressively increase in the future (Pla 2014). Soil is a non-renewable resource and its utility is defined by its intrinsic or static quality (soil forming factors and edaphic processes), which are long-term processes.

Intensive agriculture, overexploitation, and the mismanagement of soils in Spain have led to serious degradation conditions, such as erosion, low soil organic matter (SOM) contents, or salinization (Gallardo 2016). Land use and management establish its dynamic quality (soil health) and both are short- and medium-term changes. Therefore, a high-quality soil is one that promotes productivity in a sustainable way and which could absorb environmental and pathogenic pollutants while facilitating the health of plants, animals and people (Doran and Parkin 1994; Karlen et al. 1997).

Changing land use has potential impacts on other factors, such as flora and fauna, soils, surface water distribution and climate. The new environmental, economic and social challenge for the agricultural irrigation sector is to meet water demands during drought periods, which are each time more severe. So to protect those functions we must evaluate and predict the behavior of soils in time and space under a wide range of both agricultural and non-agricultural land uses, in relation to crop production, water supply and environmental quality (Pla 2014).

Historically, the Food and Agriculture Organization Land Evaluation (LE) framework (FAO 1976) has been the primary procedure employed worldwide to address local, regional, and national land use planning. In recent years computing technologies combined with Geographic Information Systems (GIS) enabled a countless number of reports and studies used to address new, important and complex environmental problems ranging from environmental pollution, nitrate leaching, and urban planning.
Most of the present and future problems of land and soil degradation, water supply and natural disasters (i.e. droughts, flooding and landslides) are attributed to climate change (Pla 2014). And at the same time, changes in soil cover and soil degradation will influence global climate changes (Pla 2002a).

The Decision Support Systems (DSS) are interactive computing platforms that integrate new Information and Communication Technologies (ICT), including engineering data and knowledge. They are excellent tools for transferring scientific knowledge to solve problems such as risk warning (De la Rosa 2013).

AndaLAND is a prototype of DSS that responds technically and globally to the need to ensure the sustainability of the agricultural use of soil and water in the Andalusian region. It helps to define the vulnerability, and the efficiency of soil use and protection in the selected target region: Andalusia (Southern Spain).

\section{Basic data warehousing}

The study area of the present work is the region of Andalusia (Figure 1). This area is located in Southern Spain and covers an area of approximately $87596 \mathrm{~km}^{2}$ (approximately 17\% of the Spanish territory). Its orography is rather complex and elevation varies between 0 and $3478 \mathrm{~m}$ above sea level (masl), with slope between 0 and $7 \%$ in growing areas. Andalusian climate is rather heterogeneous (predominated Mediterranean semi-arid), with an average annual precipitation between 300 and $2000 \mathrm{~mm}$, and average annual temperatures between $5^{\circ} \mathrm{C}$ and $18^{\circ} \mathrm{C}$.

Approximately $44 \%$ of the region is occupied by agricultural areas and $50 \%$ by natural areas. Both urban and water spaces cover 3\% each of Andalusian surface (Bermejo et al. 2011). Most of the natural vegetation is Mediterranean 


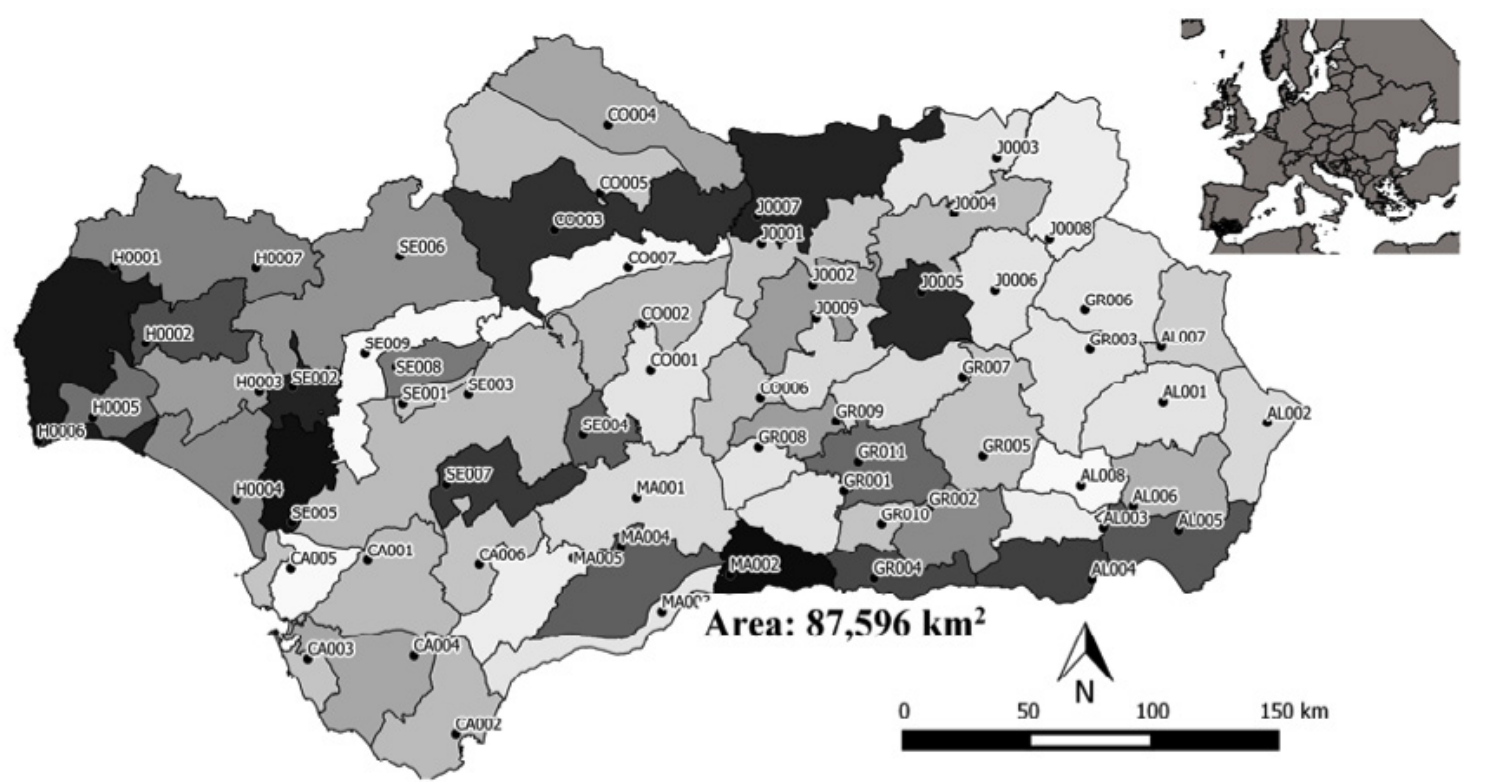

FAO/WRB 2006 of 62 natural regions Andalusia (Southern-Spain)

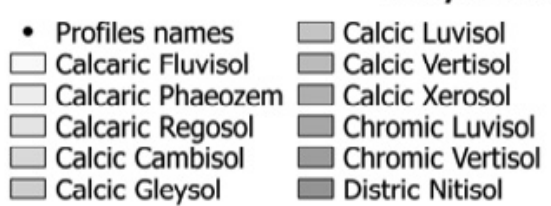

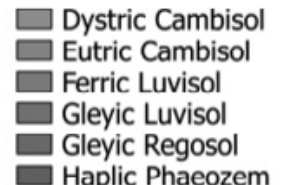

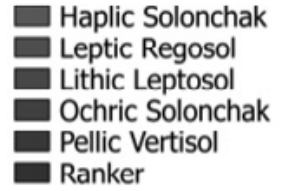

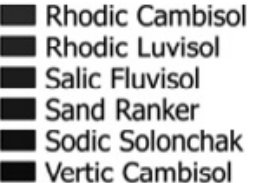

Figure 1. Location of the study area and distribution of soil types-profile names 'District and numer'- within the region (Junta de Andalucía 1984; IUSS WRB 2006).

forest, mainly evergreen trees such as oaks, pines and firs, with dense riparian forests, and Mediterranean shrubland. Agriculture in Andalusia has usually been based on wheat crops, olive trees and vineyards. It should be noted that in Southern and Southeastern Spain, large areas of land have been covered by plastic greenhouses or converted to irrigated fields, drastically changing the land use and increasing pollution and the risk of soil salinization (Gallardo 2016). In Andalusia, there is a great diversity of soil orders (Figure 1) with the main ones being Cambisol (16\%), Fluvisol (5\%), Gleysol (1\%), Leptosol (1\%), Luvisol (20\%), Nitisol (4\%), Phaeozem (7\%), Ranker (6\%), Regosol (17\%), Solonchak (4\%), Vertisol (18\%) and Xerosol (1\%) (Junta de Andalucía 1984; IUSS WRB 2006; Anaya-Romero 2013) (Annex 1).
The AndaLAND DSS is developed as a webbased application: the software runs in a server, and the user only needs access to a webpage by using an Internet browser. To begin with the system requires user registration, completing a signup form through the platform. Unrestricted public access is allowed. Accordingly, all registrations must be validated by AndaLAND administrators, in order to avoid malicious users such as spammers. Once user is validated, he/she is allowed to register his/her land (geographical location). Two procedures are possible: (i) the user can directly introduce the plot's cadastral reference or (ii) the user can do this identification through an orthophoto map-based interface tool. After this selection, AndaLAND starts an automatized collection of available data for this area, by querying public sources to which the platform has access. The 
collected information is needed to make a first assessment of the knowledge managed by AndaLAND. Additional information concerning specific characteristics of the selected plot, as well as its crop types (olive, fruit, etc) is required to generate recommendations.

The knowledge managed byAndaLAND has been generated by experts, publications (JiménezBallesta et al. 2012), legislation and regulations, etc. Such knowledge is a key source to generate recommendations. Since this knowledge is managed by a computer program, it is processed and modeled by using a language that software can use. This knowledge is structured into a set of rules. In turn, a rule can be defined as a set of conditions that must be satisfied in order to give a preset recommendation (for example, Figure 2 shows how a single rule is modeled in a computer). These rules are stored in a database: AndaLAND's "knowledge database".

The basic operation of AndaLAND relies on two main components: (1) its "knowledge database" and (2) input data required to evaluate the existing knowledge and generate recommendations.

Three types of data sources are used in the design of AndaLAND's basic data warehousing
(Figure 3): external data, additional userspecified data, and AndaLAND's in-house data.

External data are accessed through existing interoperable protocols such as Web Map Services (WMS). This mechanism is used for automating data gathering once the user has proceed with the geographical location registry, as explained above. A large data set is available, and it covers a significant part of user needs. In order to optimize AndaLAND's performance, these external data are not always queried and retrieved in real-time: data is also stored and updated in an internal database.

By using WMS, AndaLAND is fed with available databases from public mapping services, such as the Andalusian Environmental Information Network (REDIAM) (for instance, soil erosion and desertification), and the Spanish Ministry of Agriculture, Food and Environment (MAGRAMA) (for example, protected natural areas and areas vulnerable to nitrates). In addition, AndaLAND incorporates databases from other external sources, such as Microcomputer-based Land Evaluation Information System (MicroLEIS DSS), the Geographic Information System for the Common Agricultural Policy (SIGPAC), characterization and mapping of the Agricultural

\begin{tabular}{|c|c|}
\hline Human rule & Modeled rule \\
\hline $\begin{array}{l}\text { It is not advisable to apply the tech- } \\
\text { nique of furrow irrigation on land with } \\
\text { slopes greater than } 2 \% \text { and surface } \\
\text { two hectares }\end{array}$ & $\begin{array}{l}\text { rule"Pendientes mayores de } 0 \text { a } 2 \% \text { fincas mayores de } \\
\text { 5ha" } \\
\text { when } \\
\text { Scene ( getLandProperty("pdte_media") != null, } \\
\text { Float.parseFloat(getLandPropertyValues("pdte_me- } \\
\text { dia").get( } 0 \text { )) > } 2.0 \text {, } \\
\text { getLandProperty("nu_area") != null, } \\
\quad \text { Float.parseFloat(getLandPropertyValues("nu_- } \\
\text { area").get( } 0) \text { ) } 5.0 \text { ) } \\
\text { r : Recommendation ( ) } \\
\text { then } \\
\text { r.removeIrrigation( Recommendation.GROOVES ); } \\
\text { end }\end{array}$ \\
\hline
\end{tabular}

Figure 2. An example of modeled rule of AndaLAND. 


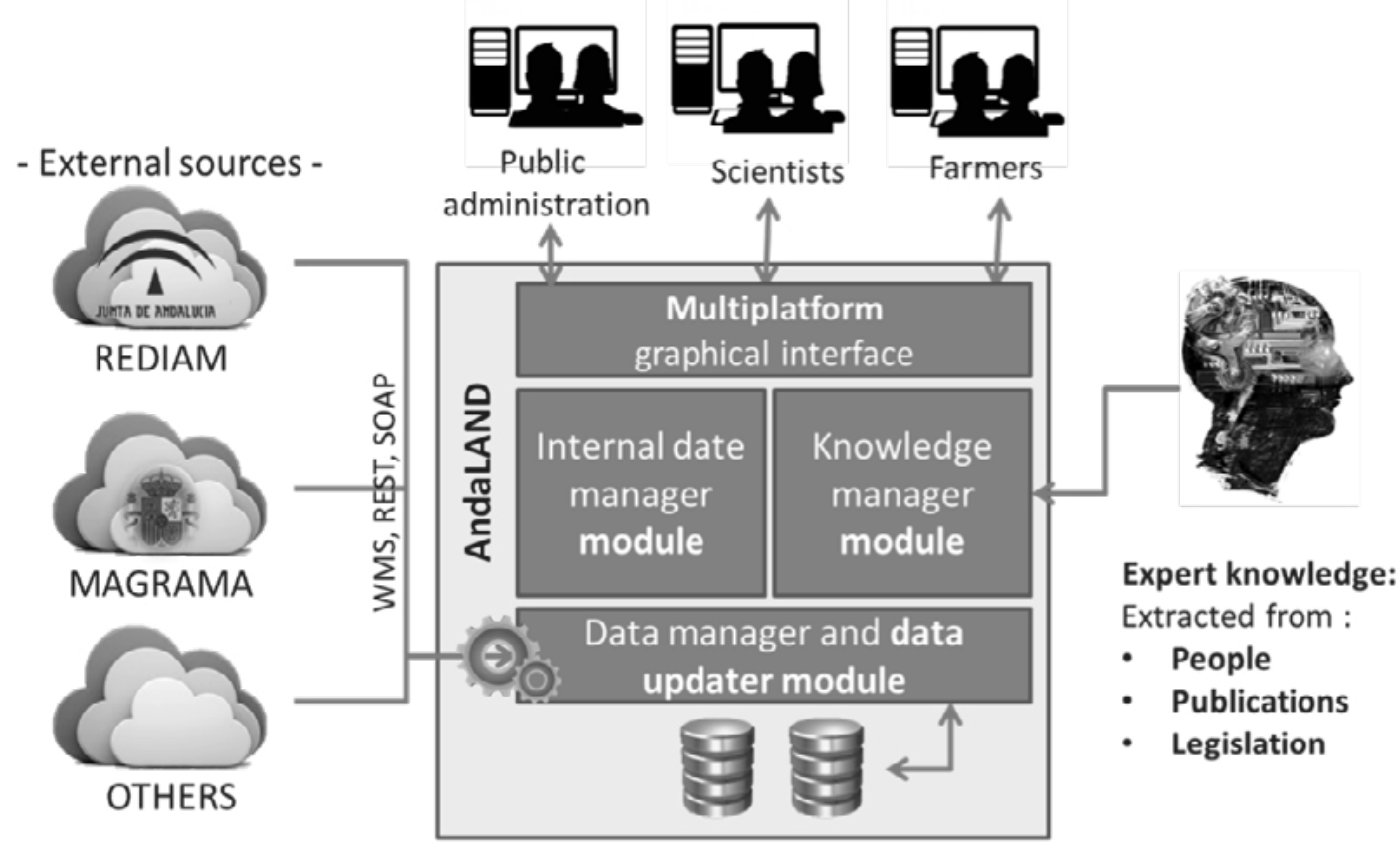

Figure 3. Funtional struture of AndaLAND.

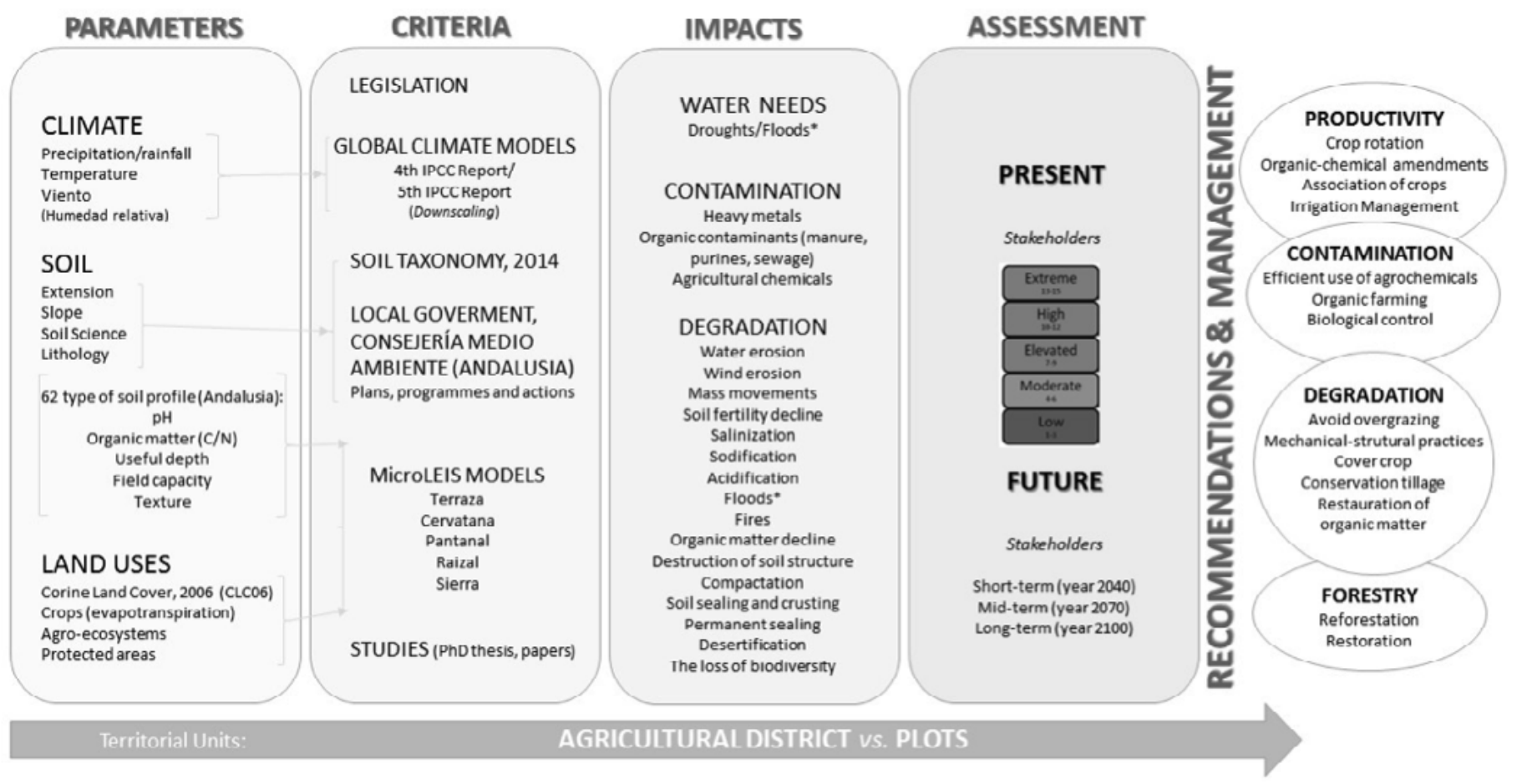

Figure 4. Methodological scheme of AndaLAND. 
Regions of Andalusia (Fernández et al. 2011) and the Spanish Information System on Soils (SEISnet).

In case the user has specific knowledge on land data, he/she can also easily feed the system with them.

Finally, AndaLAND has an in-house data set, such as a catalogue of information on climate, soil and soil management. Among other features, AndaLAND predicts the optimum land use and advises on the best soil management practices, at a plot level and customized for each soil type, in order to achieve optimum biomass productivity, and simultaneously minimize environmental vulnerability. Climate change scenarios are considered jointly with other relevant global change elements, such as land use change.

In AndaLAND, soil evaluation is based on decision rules (decision tree). This method was established from Drools (a powerful hybrid reasoning system), using agrological rules for determining soil capacity in plots (Land capability, criteria of the Soil Conservation Service of USA, Klingebiel and Montgomery 1961; and Soil Fertility Capability Classification, Buol et al. 1975). The tool is capable of evaluating individually more than 6 million of plots currently existing in the Andalusian region.

The methodological work was made following the scheme shown in Figure 4.

\subsection{Climate database}

Climate data for current and future scenarios were obtained from the Spanish Weather Agency (AEMET, http://www.aemet.es/) for 62 weather stations spread through the total area of the Andalusian region. AEMET provides regionalized climate change projections generated by the ENSEMBLES project for a mean scenario of emissions (A1B). Four qualitative storylines yield four sets of scenarios: $A 1, A 2, B 1$ and $B 2$. The $A 1$ describes a future world of very rapid economic growth, global population that peaks in mid-century and declines thereafter, and the rapid introduction of new and more efficient technologies. The A2 is a very heterogeneous world, which is self-reliance and preservation of local identities, per capita economic growth and technological change are more fragmented and slower than in other. The B1 shows a convergent world with the same population (scenario A1), but with rapid changes in economic structures toward a service and information economy (global solutions but without additional climate initiatives). The B2 describes a world with continuously increasing global population at a rate lower than $A 2$, intermediate levels of economic development, and less rapid and more diverse technological change than B1 and A1. The A1B scenario describes a mid-line scenario between scenarios $\mathrm{A} 2$ and $\mathrm{B} 1$, a balance across all sources, assuming a future world of very rapid economic growth, low population growth and fast introduction of new and more efficient technologies (IPPC 2007). In climatological applications the average climate over a 30 -year period is needed to define the reference or baseline climate. In this context and following IPCC (2007), four periods have been considered in this study: 1961-2000 (baseline climate period), 2011-2040 (the "near-future" period), 2041-2070 (the "mid-future" period) and 20712100 (the "far-future" period). This information allows future predictions about where and when it will produce increase in temperature, or declining rainfall, and type of variation for these values.

Data storage and harmonization was performed with the Climate Data Base (CDBm) (De la Rosa 1986). The CDBm is a major component of the MicroLEIS DSS system (De la Rosa and AnayaRomero 2004) and is a computer-based tool for the organization, storage, and manipulation of agro-climatic data for land evaluation. Basic data stored in the CDBm are the mean values of the daily dataset for a particular month of a set of temperature and precipitation variables. Variables used in this study were: mean, maximum and minimum temperature $\left({ }^{\circ} \mathrm{C}\right)$ and precipitation $(\mathrm{mm})$. 
A hydrological approach to the evaluation and prediction of soil and water conservation is essential for adequate development, selection and application of sustainable and effective land use and management practices (Pla 2002b). The information about climate values (rainfall and temperature) was registered in a group of Geographic Information System (GIS) features (raster format) by downscaling. This was developed to obtain local-scale weather and climate, particularly at the surface level, from regional-scale atmospheric variables that are provided by Global Climate Models).

\subsection{Soil database}

Soil data was obtained from the Spanish Information System on Soils SEIS. net database (www.evenor-tech.com) which stores soil information from more than 1000 soil profiles. Soil data harmonization was performed with the Soil Data Base (SDBm) Plus component of MicroLEIS DSS. This soil database is a multilingual soil profile database that stores and retrieves geo-referenced soil attribute data collected in soil surveys and laboratories.

The SDBm Plus database is considered an essential part of any support system for the exploration of decision-making for sustainable agriculture development. However, this sophisticated database can be useful for independent storage of primary soil information assembled at regional or national level, or for temporary storage of data accumulated during a particular soil survey or local monitoring exercise (De la Rosa and Anaya-Romero 2004).

This database uses the following parameters: useful soil depth, type of texture, organic matter, type of drainage and water retention.

\subsection{Management database}

Management data was also obtained from the SEIS.net database (www.evenor-tech.com) and integrated in the agricultural Management Data Base (MDBm), a component of MicroLEIS DSS.
The MDBm dataset consists of geo-referenced agricultural data on a particular land use system, structured and stored as a file. A menu system guides the user through a sequence of options to capture the management practices followed on a specific plot. This knowledge was integrated into the software and it was obtained through interviews with farmers (based on type of use and land management), which was captured, stored, processed and transfered. By using $\mathrm{MDBm}$, the agricultural management data are collected and put in a searchable format. This database is easily accessible and of enormous value because it can be searched according to the following variables: the farms and plots, the crops characteristics, the management operations, or the farmers' observations. For each one of these variables, the search can be done by many other management variables, and be used as land evaluation model inputs. Management data for soil evaluation was obtained from this database (De la Rosa and Anaya-Romero 2004).

On the other hand, site data, such as elevation and slope, were extracted from the Digital Elevation Model of Andalusia (ICA 1999) with 100 metres spatial resolution.

\section{Land evaluation rules for irrigation management}

Irrigation management rules have been incorporated into AndaLAND for enabling the DSS to provide recommendations on how to manage irrigation in the studied plot. The system makes suggestions on the most adequate irrigation system and strategy as well as on the best method to schedule irrigation in the plot under study. Regarding the irrigation system, AndaLAND chooses between furrow, sprinkling, localized irrigation and hydroponics. Regarding 
the irrigation strategy, the system considers suplementary (or complementary) irrigation, low frequency deficit irrigation, sustained deficit irrigation, regulated deficit irrigation and full irrigation (Fernández 2014a). Concerning the irrigation scheduling method, AndaLAND chooses between the crop coefficient method and four plant-based methods, one of them conventional (monitoring of the plant water status with a Scholander-type pressure chamber) and other three new, automatic methods, based on measurements of sap flow, trunk diameter variation and leaf turgor pressure (Fernández 2014b). Each one of the mentioned options are related in the system to main soil, crop, and climate characteristics, as well as to water availabilty and production target (quantity or quality). Depending on these variables, AndaLAND provides the most suitable options for irrigation system, irrigation strategy and irrigation scheduling method. This first version of AndaLAND does not provide any further information for scheduling irrigation. Yet the
DDS is designed for implementing in the future a module to schedule irrigation of plots previously instrumented with the sensors and related equipment of one of the five methods mentioned above.

\section{Software architecture and design of AndaLAND}

AndaLAND has been developed as a web site, based in Java Plataform Enterprise Edition (JavaEE or J2EE), and used the PostgreSQL relational database for data storage purposes. It is shown in AndaLAND's computer system operation (Figure 5).

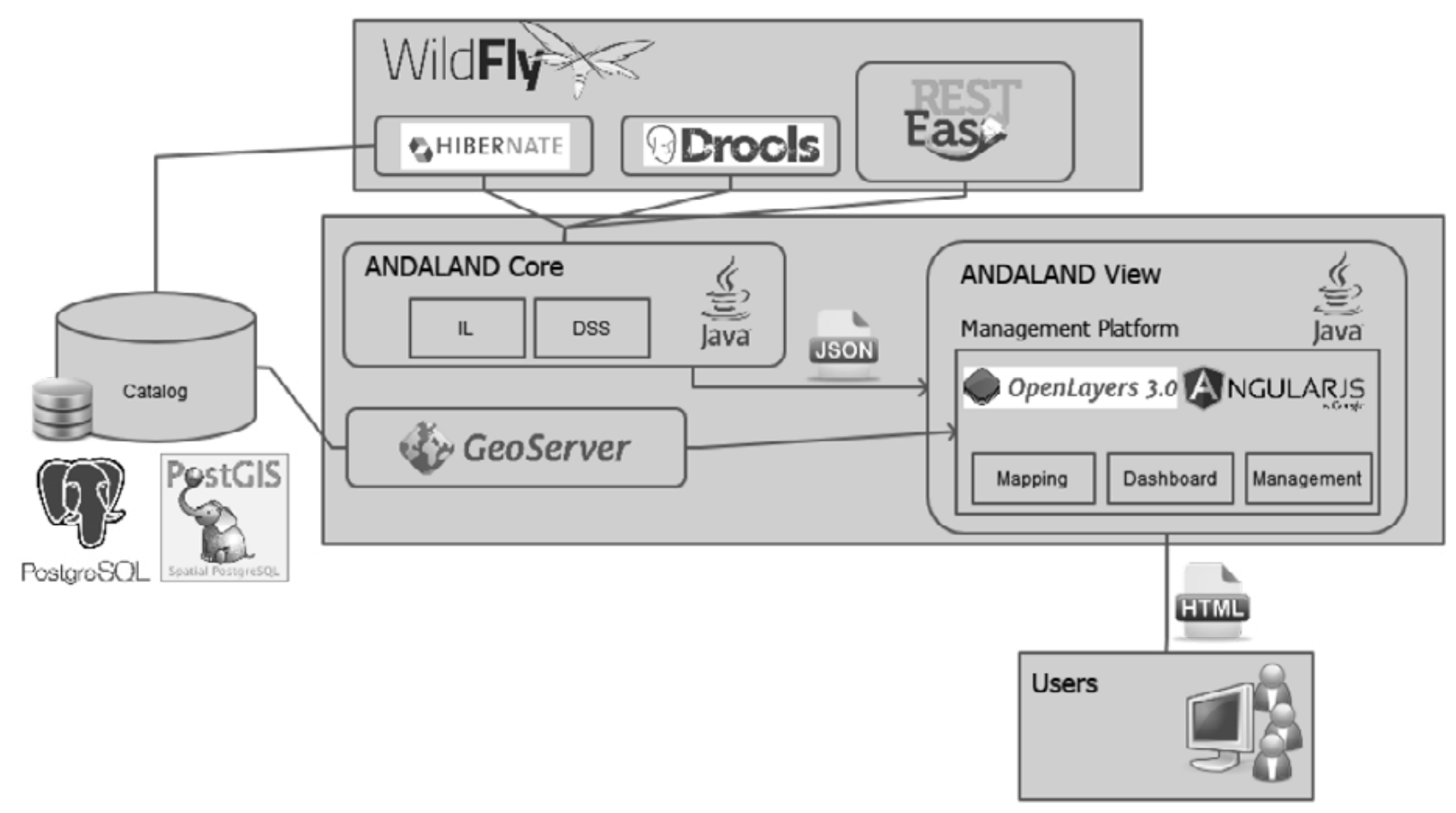

Figure 5. Computer system operation of AndaLAND. 
One of the most important objectives targeted when developing AndaLAND was to design the system as a living data repository, where anyone could store all the land-related information. In order to achieve this goal, the system was developed fulfilling the following design criteria and features:

- Based on an Interoperability Layer (IL), the system uses a component which is capable of retrieving information from remote systems providing data through standard protocols (such as WMS, Web Feature Service WFS, Extensible Markup Language XML, Geography Markup Language GML, etc) and to be queried about a spatial point in particular.

- ETL (Extract, Transform, and Load) data management paradigm: this process permits the system to get the data from homogeneous or heterogeneous data sources (from $\mathrm{IL}$ ), transforming the data to an appropriate structure for storage purposes, and loading it into the database. This paradigm lets the system to store all the information received from IL component, for later use.

- Datawarehouse: the system is allowed to store all the information with a timestamp and old data is stored as a historical database. A Datawarehouse always has the information of each of the parameters in its latest version so that the user can dispose of it for analysis. Therefore, none of the data is deleted, but it becomes part of the historical database, and it could be used to analyze parameter time evolution.

Based in the data repository, and using this data as input, the system could infer the current land state and generate use recommendations to the land owner. The technology used to this feature is a inference engine based in rules, known as Drools. It uses a big amount of data (in our case the land properties, and agricultural user needs, stored in the database) for solving problems using rules that define expert knowledge on the issue (agricultural uses to minimize the impact of climate change, deficit irrigation methods, etc.), and as output the engine returns a group of states that represents the application of the expert knowledge on the input data, that represent a case of study.

AndaLAND is able to obtain land information automatically, and users can also introduce certain parameters in the system, for a better definition of their watering needs (for example: type of plant, if their plantation is irrigated, tree density, preference for quality over quantity in production, etc.) but these users parameters are not required to allow the inference system work, it is optional.

\section{User validation}

Many DSS are designed by research centers, and they are effectively transferred to private sector and public administration. Furthermore, it relies on a technology that is both user-friendly and useful for local government officials, their consultants and the elected decision makers. For this reason, the project managers decided to present the AndaLAND DSS to a group of potential users or stakeholders in a specific workshop (http://www.recupera2020.csic.es/es/ etiquetas/andaland). This approach is foreseen to introduce significant changes in the use of ICT in agriculture (De la Rosa et al. 2003).

The composition of the user group for system validation was determined by twenty-one attendees of the workshop. This stakeholder group was formed by local agents, such as farmers and land users, representatives of the local authorities and local Non-Governmental Organizations (NGOs) (Figure 6). All these stakeholders have specific knowledge and extensive experience in the study area. Although the biggest group was made up of researchers and other academic players ( $44 \%$ of the participants), it could be a bit unrepresentative. 

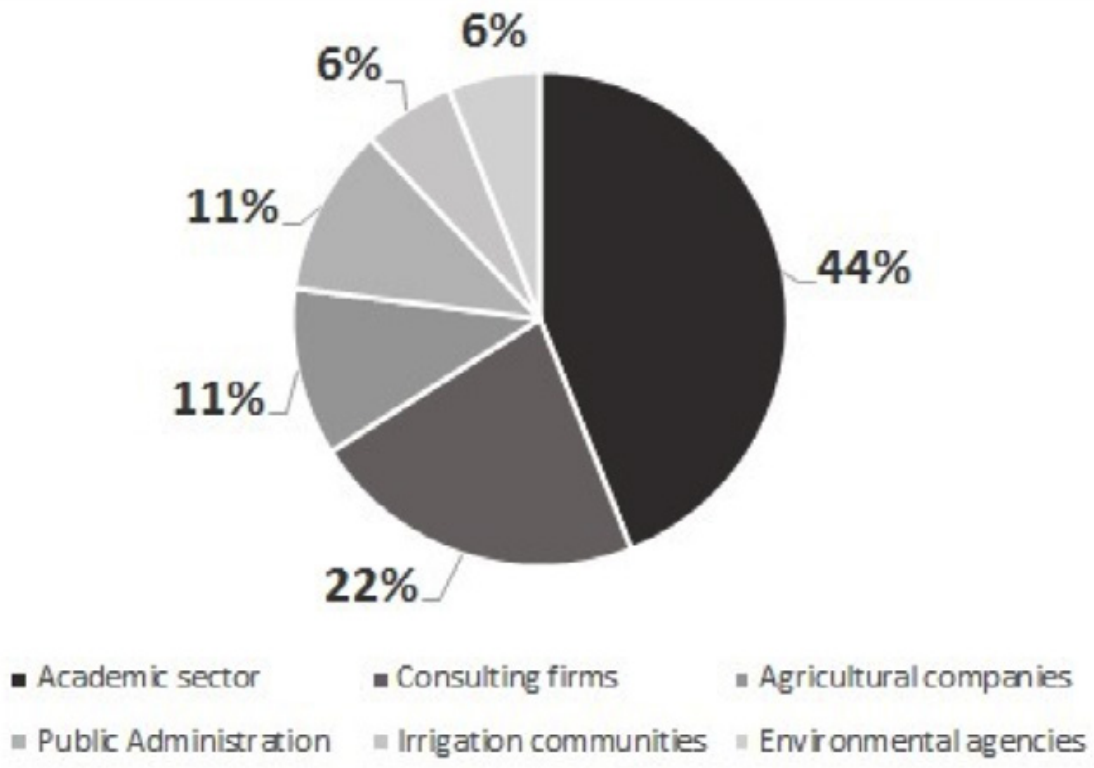

Figure 6. Percentage distribution of stakeholders attending to AndaLAND workshop.

Also attending were consultants and technical staff of public administration with different levels of experience in the rural environment, and who could suggest alternative techniques for managing and evaluating the agricultural production system.

At present, AndaLAND is still a prototype. During the workshop, a practical demostration of the application was made and attendees tested the usability (it is shown in Figure 7). After this, they worked about what is the actual situation about techniques (land management, crops and agrochemicals used) and agricultural policies (the Common Agricultural Policy-CAP), and several surveys were made about it. So it was demonstrated the extraordinary synergy that occurs between ICT and environmental management in the search for a comprehensive and sustainable development. It showed that adaptation and improvement are needed, specially the current policies, plans and programs. These policies, plans and programs, and the most used irrigation technologies were planned as a response to real or proposed problems or difficulties in agriculture. The efficiency, flexibility and control of water use must move towards productive orientation of those farms whose crops have greater future within the framework of the new CAP, greater demand in markets (high-quality products), and higher economic margin, and which are more likely to create jobs (Corominas Masip 2014).

\section{Discussion}

Most of these models require indeed high quality input data, and a direct relationship to the predictive performance of the models and model complexity outcomes. Complex models also require considerable judgment and expertise, and the availability of high quality data results in a trade-off in the exponential increase in costs. The decision tree methodology has limitations, inaccuracies and fuzzy logic. In order to reduce potential inconsistencies or errors, it would be necessary to calibrate the system by flushing and interpretation of local experiences or pilot projects with experimental data (Gehrke et al. 1999; Quinlan 1986). The main reason is the size, speed and interconnections in a complex system such as soil (physical, chemical, biological and anthropogenic). 


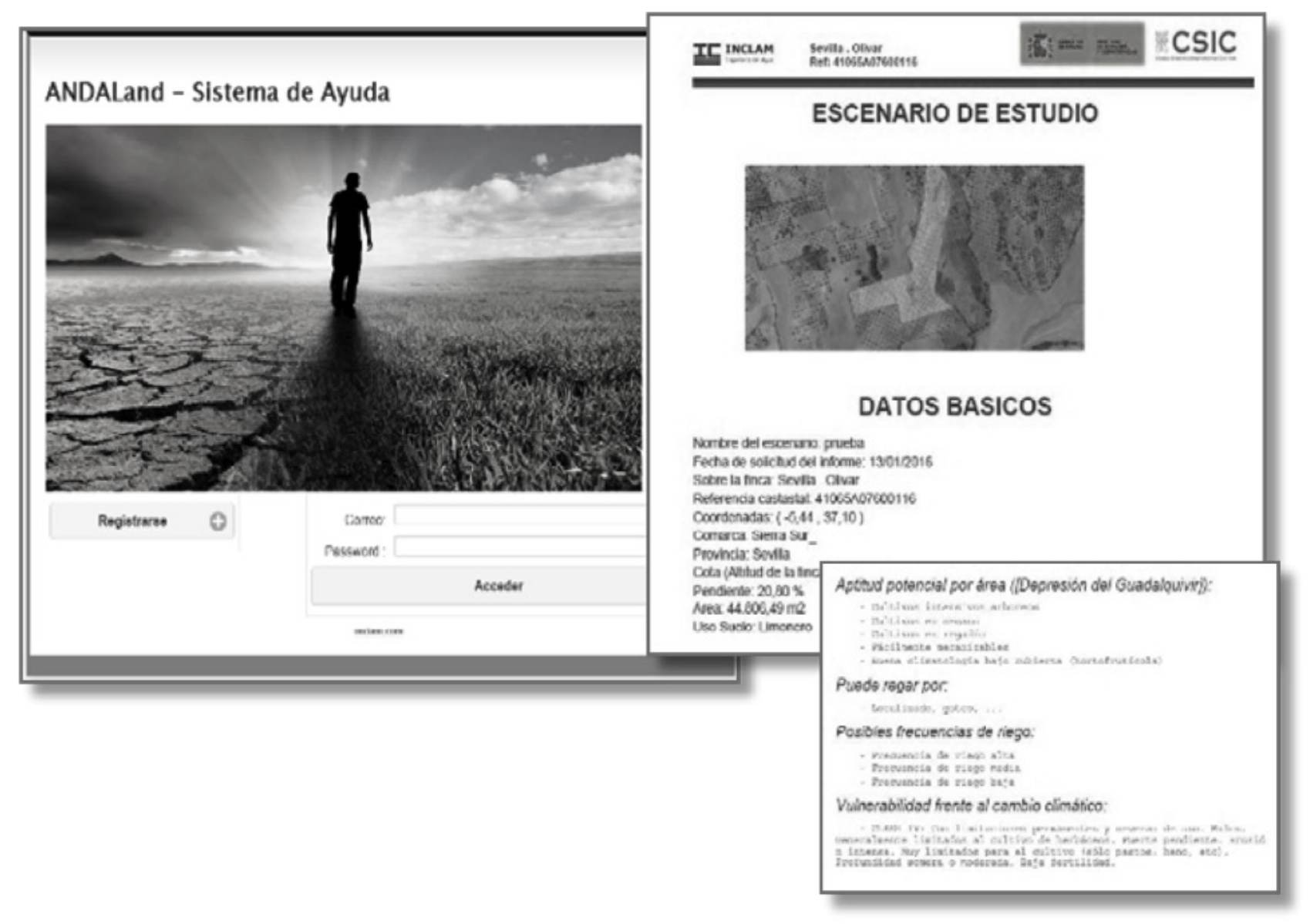

Figure 7. An example of AndaLAND's final output.

Widely applied models in agriculture are Microcomputer-based Land Evaluation Information System DSS (MicroLEIS DSS) (http://www. evenor-tech.com), Automated Land Evaluation System (ALES) (http://www.css.cornell.edu/ landeval/ales/ales.htm), and many applications available through the Land Evaluation and Site Assessment (LESA http://soils.usda.gov), the Agricultural Land Classification systems (ALC http://www.defra.gov.uk), largely used in the USA and UK, respectively. Recently, in 2015, the project named sigAGROAsesor DSS (LIFE+11 ENV/ES/641) has been completed. It is a webGIS developed at a national level in Spain (http://agroasesor.es/es/el-proyecto.html; http://agroasesor.prodevelop.es).
An integrated approach to the use, management and conservation of soil and water resources is futher justified by the close relationship between soil and water quantity and quality (Pla 2014).

\section{Concluding comments}

The work presented here has generated a broad, powerful and updated database on climate, soil, and use and management of plots and farms in Andalusia. Therefore, AndaLAND is a powerful DSS which provides environmental and socioeconomic benefits in the short-, mediumand long-term, depending on the final users. 
Soil evaluation using AndaLAND will be very useful from both the political and administrative (regional or generalized scale) and the technical and agricultural (local or detailed) standpoints, when the most appropriate alternative of land use and management is chosen according to given social and economical constraints.

The AndaLAND DSS could achieve a model of sustainable and multifunctional agriculture (CSA, Climate-Smart Agriculture) specially in the Mediterranean region, and in particular, Southern Spain. This is one of the areas in the country where water resources are most scarce, and also one of the most vulnerable to climate change.

\section{Acknowledgements}

This research was funded by the Spanish Ministry of Economy and Competitiveness (MINECO) and the European Regional Development Fund (ERDF) within the framework of the new Precommercial Public Procurement (CPP). The AndaLAND DSS has been jointly developed by the Spanish National Research Council (CSIC), the Institute of Natural Resources and Agrobiology of Seville (IRNAS-CSIC) and two Spanish companies: INCLAM, specialized in water and environmental engineering; and EVENOR-TECH, specialized in Information and Comunication Technologies (ICT) applied to land use planning.

\section{REFERENCES}

- Anaya-Romero M. 2013. Soil data from Spain (Andalusia). In: Weynants et al., editors. European Hydropedological Data Inventory (EU-HYDI). 08/2013. Publications Office of the European Union. p. 57-62. DOI: 10.2788/5936. ISBN: 978-92-79-32355-3.

- Bermejo D, Cáceres F, Moreira JM, Montes JE, Sánchez S, Laguna D, Caballo A, Anaya-Romero M, Asensio B. 2011. Medio siglo de cambios en la evolución de usos del suelo en Andalucía 1956-2007. Consejería de Medio Ambiente de la Junta de Andalucía.

- Buol SW, Sánchez PA, Cate RB, Granger MA. 1975. Soil fertility capability classification: a technical soil classification system for fertility management. In: Bornemisza E, Alvarado A, editors. Soil Management in Tropical America. Raleigh, NC: N. C. State Univ. p. 126145.

- Corominas Masip J. 2014. Desarrollo Rural y DMA (Directiva Marco del Agua): ¿Cómo incidirán en los regadíos? In: Jornada El Feader y su contribución a los objetivos ambientales de la UE, WWF; 2014 Oct 14; Madrid, Spain

- De la Rosa D. 2013. Una agricultura a la medida de cada suelo: desde el conocimiento científico y la experiencia práctica a los sistemas de ayuda a la decisión. Acto de recepción como Académico Numerario; 2013 May 13; Real Academia Sevillana de Ciencias, Sevilla, Spain.

- De la Rosa D, Anaya-Romero M. 2004. MicroLEIS DSS: FOR Planning Agro-Ecological Soil Use and Management Systems. Sevilla, Spain: Institute of Natural Resources and Agrobiology, CSIC.

- De la Rosa D, Mayol F, Díaz-Pereira E, Fernández M, De la Rosa J. 2003. A land evaluation decision support system (MicroLEIS DSS) for agricultural soil protection with special reference to the Mediterranean region. Environmental Modelling and Software 19:929-942.

- De la Rosa D, Mayol F, Moreno JA, Rosales A. 1986. CDBm, monthly Climate Database. MicroLEIS 4.1. Exploring the Agro-ecological Limits of Sustainability. Sevilla, Spain: IRNAS Press.

- Doran JW, Parkin TB. 1994. Defining and assessing soil quality. In: Doran JW, Coleman DC, Bezdicek DF, Stewart BA, editors. Defining Soil Quality for a Sustainable Environmental. SSSA Special Publication, Number 35. Madison, Wisconsin, USA: Soil Science Society of America. p. 3-21.

- FAO. 1976. A Framework for Land Evaluation. FAO Soils Bulletin 52. Rome: FAO. 79 p.

- Fernández JE. 2014a. Understanding olive adaptation to abiotic stresses as a tool to increase crop performance. Environmental and Experimental Botany 103:158-179. 
- Fernández JE. 2014b. Plant-based sensing to monitor water stress: Applicability to commercial orchards. Agricultural Water Management 142:99-109.

- Fernández J, Checa M, Esteban B, Sánchez J, Curt MD, Mosquera F, Romero L, Aguado PL. 2011. Descripción de las características agrarias y geográficas de las provicias de España. Tomo 1: Comunidades Autónomas (Sinopsis). Grupo de Agroenergética E.T.S.I. Agrónoma, Universidad Politécnica de Madrid. Madrid: Ministerio de Medio Ambiente y Medio Rural y Marino (MARM). p. 7-38.

- Gallardo JF, editor. 2016. The Soils of Spain. World Soils Book Series. Printforce, The Netherlands: Springer International Publishing Switzerland 2016. 197 p.

- Gehrke J, Loh W-Y, Ramakrishnan R. 1999. Classification and regression: money can grow on trees. Tutorial notes, KDD'99 International Conference on Knowledge Discovery and Data Mining; 1999 Aug 15-18; San Diego, California, USA. p. 1-73.

- ICA. 1999. Modelo Digital de Elevaciones. 100 m. CDROM. Instituto de Cartografía de 613 Andalucía. Sevilla: Consejería de Obras Públicas y Transportes de la Junta de Andalucía.

- IPCC. 2007. Climate change 2007: The Physical Science Basis. Cambridge/New York: Cambridge University Press.

- IUSS Working Group WRB. 2006. World Reference Base for Soil Resources 2006. World Soil Resources Reports No. 103. Rome: FAO.

- Jiménez-Ballesta R, Íñigo V, Andrades MS, AlonsoMartirena Jl, Marín A. 2012. Soil property variability in a humid natural Mediterranean environment: La Rioja, Spain. Spanish Journal of Soil Science V2, N1:38-54.

- Junta de Andalucía. 1984. Catálogo de suelos de Andalucía. Sevilla: Agencia de Medio Ambiente de la Junta de Andalucía.

- Karlen DL, Mausbach MJ, Doran JW, Cline RG, Harris RF, Schuman GE. 1997. Soil quality: a concept, definition and framework for evaluation. Soil Science Society of America J. 61:4-10.

- Klingebiel AA, Montgomery PH. 1961. Land capability classification. USDA Agricultural Handbook 210. Washington, DC: US Government Printing Office.

- Pla I. 2002a. Assessment of Environment impacts derived of soil and water conservation practices. In: Sustainable Utilization of Global Soil and Water Resources. Volume III. Beijing (China): Tsinghua University Press. p. 282-290.

- Pla I. 2002b. Hydrological approach to soil and water conservation. In: Rubio JL, Morgan RPC, Asins S, Andreu V, editors. Man and Soil at the Third Millenium. Volume I. Logroño (España): Geoforma Ed. p. 65-67.
- Pla I. 2014. Advances in soil conservation research: challenges for the future. Spanish Journal of Soil Science V4, N3:265-282.

- Quinlan R 1986. Learning decision tree classifiers. ACM Computing Surveys 28:71-72. 


\begin{tabular}{|c|c|c|c|c|c|}
\hline Profile & USDA/STS 2015 & FAO/WRB 2006 & Profile & USDA/STS 2015 & FAO/WRB 2006 \\
\hline AL01 & Xerorthents & $\begin{array}{l}\text { Calcaric } \\
\text { Regosol }\end{array}$ & GR11 & $\begin{array}{l}\text { Aquic } \\
\text { Xerofluvents }\end{array}$ & $\begin{array}{l}\text { Gleyic } \\
\text { Regosol }\end{array}$ \\
\hline AL02 & $\begin{array}{l}\text { Calcixerollic } \\
\text { Xerochrepts }\end{array}$ & $\begin{array}{l}\text { Calcic } \\
\text { Cambisol }\end{array}$ & H001 & $\begin{array}{l}\text { Lithic } \\
\text { Xerochrepts }\end{array}$ & $\begin{array}{l}\text { Sand } \\
\text { Ranker }\end{array}$ \\
\hline AL03 & $\begin{array}{l}\text { Rupticlithic } \\
\text { Rendolls }\end{array}$ & $\begin{array}{l}\text { Calcaric } \\
\text { Phaeozem }\end{array}$ & H002 & $\begin{array}{l}\text { Lithic } \\
\text { Xerorthents }\end{array}$ & $\begin{array}{l}\text { Leptic } \\
\text { Regosol }\end{array}$ \\
\hline AL04 & $\begin{array}{l}\text { Salorthidic } \\
\text { Fluvaquents }\end{array}$ & $\begin{array}{l}\text { Ochric } \\
\text { Solonchak }\end{array}$ & H003 & $\begin{array}{l}\text { Entic } \\
\text { Pelloxererts }\end{array}$ & $\begin{array}{l}\text { Chromic } \\
\text { Vertisol }\end{array}$ \\
\hline AL05 & $\begin{array}{l}\text { Vertic } \\
\text { Haplargidos }\end{array}$ & $\begin{array}{l}\text { Haplic } \\
\text { Solonchak }\end{array}$ & H004 & $\begin{array}{l}\text { Entic } \\
\text { Xerumbrepts }\end{array}$ & $\begin{array}{l}\text { Dystric } \\
\text { Cambisol }\end{array}$ \\
\hline AL06 & $\begin{array}{l}\text { Torrertic } \\
\text { Camborthids }\end{array}$ & $\begin{array}{l}\text { Calcic } \\
\text { Xerosol }\end{array}$ & H005 & $\begin{array}{l}\text { Aquic } \\
\text { Palexeralfs }\end{array}$ & $\begin{array}{l}\text { Gleyic } \\
\text { Luvisol }\end{array}$ \\
\hline AL07 & $\begin{array}{l}\text { Palexerollic } \\
\text { Xerochrepts }\end{array}$ & $\begin{array}{l}\text { Calcic } \\
\text { Gleysol }\end{array}$ & H006 & $\begin{array}{l}\text { Salorthidic } \\
\text { Fluvaquent }\end{array}$ & $\begin{array}{l}\text { Salic } \\
\text { Fluvisol }\end{array}$ \\
\hline AL08 & $\begin{array}{l}\text { Typic } \\
\text { Xerofluvents }\end{array}$ & $\begin{array}{l}\text { Calcaric } \\
\text { Fluvisol }\end{array}$ & H007 & $\begin{array}{l}\text { Dystric } \\
\text { Eutochrepts }\end{array}$ & $\begin{array}{l}\text { Eutric } \\
\text { Cambisol }\end{array}$ \\
\hline CA01 & $\begin{array}{l}\text { Chromic } \\
\text { Pelloxererts }\end{array}$ & $\begin{array}{l}\text { Calcic } \\
\text { Vertisol }\end{array}$ & J001 & $\begin{array}{l}\text { Typic } \\
\text { Rhodoxeralfs }\end{array}$ & $\begin{array}{l}\text { Calcic } \\
\text { Luvisol }\end{array}$ \\
\hline CA02 & $\begin{array}{l}\text { Typic } \\
\text { Chromoxererts }\end{array}$ & $\begin{array}{l}\text { Calcic } \\
\text { Vertisol }\end{array}$ & $\mathrm{J} 002$ & Chromoxererts & $\begin{array}{l}\text { Chromic } \\
\text { Vertisol }\end{array}$ \\
\hline CA03 & $\begin{array}{l}\text { Calcic } \\
\text { Rhodoxeralfs }\end{array}$ & $\begin{array}{l}\text { Calcic } \\
\text { Luvisol }\end{array}$ & J003 & $\begin{array}{l}\text { Vertic } \\
\text { Palexeralfs }\end{array}$ & $\begin{array}{l}\text { Calcaric } \\
\text { Regosol }\end{array}$ \\
\hline CA04 & Palexeralfs & $\begin{array}{l}\text { Chromic } \\
\text { Luvisol }\end{array}$ & J004 & $\begin{array}{l}\text { Typic } \\
\text { Chromoxererts }\end{array}$ & $\begin{array}{l}\text { Calcic } \\
\text { Vertisol }\end{array}$ \\
\hline CA05 & $\begin{array}{l}\text { Rendollic } \\
\text { Arents }\end{array}$ & $\begin{array}{l}\text { Calcaric } \\
\text { Fluvisol }\end{array}$ & J005 & $\begin{array}{l}\text { Ruptic-Lithic- } \\
\text { Rhodoxeralfs }\end{array}$ & $\begin{array}{l}\text { Rhodic } \\
\text { Cambisol }\end{array}$ \\
\hline CA06 & Rhodoxeralfs & $\begin{array}{l}\text { Calcic } \\
\text { Luvisol }\end{array}$ & J006 & $\begin{array}{l}\text { Rendollic } \\
\text { Xerochrepts }\end{array}$ & $\begin{array}{l}\text { Calcaric } \\
\text { Regosol }\end{array}$ \\
\hline CO01 & $\begin{array}{l}\text { Rendollic } \\
\text { Xerorthents }\end{array}$ & $\begin{array}{l}\text { Calcaric } \\
\text { Regosol }\end{array}$ & J007 & $\begin{array}{l}\text { Xeroshreptic } \\
\text { Haploxeralfs }\end{array}$ & $\begin{array}{l}\text { Rhodic } \\
\text { Luvisol }\end{array}$ \\
\hline $\mathrm{CO02}$ & $\begin{array}{l}\text { Typic } \\
\text { Chromoxererts }\end{array}$ & $\begin{array}{l}\text { Calcic } \\
\text { Vertisol }\end{array}$ & J008 & $\begin{array}{l}\text { Lithic } \\
\text { Rendolls }\end{array}$ & $\begin{array}{l}\text { Calcaric } \\
\text { Phaeozem }\end{array}$ \\
\hline $\mathrm{COO3}$ & $\begin{array}{l}\text { Lythic } \\
\text { Xerochrepts }\end{array}$ & Ranker & J009 & $\begin{array}{l}\text { Rendollic } \\
\text { Xerochrepts }\end{array}$ & $\begin{array}{l}\text { Calcic } \\
\text { Cambisol }\end{array}$ \\
\hline COO4 & $\begin{array}{l}\text { Typic } \\
\text { Xerochrepts }\end{array}$ & $\begin{array}{l}\text { Chromic } \\
\text { Luvisol }\end{array}$ & MA01 & $\begin{array}{l}\text { Calcixerollic } \\
\text { Xerochrepts }\end{array}$ & $\begin{array}{l}\text { Calcic } \\
\text { Cambisol }\end{array}$ \\
\hline CO05 & $\begin{array}{l}\text { Typic } \\
\text { Haploreralfs }\end{array}$ & $\begin{array}{l}\text { Calcic } \\
\text { Luvisol }\end{array}$ & MA02 & $\begin{array}{l}\text { Lithic } \\
\text { Xerochrepts }\end{array}$ & $\begin{array}{l}\text { Vertic } \\
\text { Cambisol }\end{array}$ \\
\hline CO06 & Haploxeralfs & $\begin{array}{l}\text { Calcic } \\
\text { Luvisol }\end{array}$ & MA03 & $\begin{array}{l}\text { Rendollic } \\
\text { Xerorthents }\end{array}$ & $\begin{array}{l}\text { Calcaric } \\
\text { Regosol }\end{array}$ \\
\hline $\mathrm{CO07}$ & $\begin{array}{l}\text { Typic } \\
\text { Xerofluvents }\end{array}$ & $\begin{array}{l}\text { Calcaric } \\
\text { Fluvisol }\end{array}$ & MA04 & Haploxerolls & $\begin{array}{l}\text { Haplic } \\
\text { Phaeozem }\end{array}$ \\
\hline GR01 & Xerorthents & $\begin{array}{l}\text { Calcaric } \\
\text { Regosol }\end{array}$ & MA05 & $\begin{array}{l}\text { Udic } \\
\text { Haplustolls }\end{array}$ & $\begin{array}{l}\text { Calcaric } \\
\text { Phaeozem }\end{array}$ \\
\hline
\end{tabular}




\begin{tabular}{|c|c|c|c|c|c|}
\hline Profile & USDA/STS 2015 & FAO/WRB 2006 & Profile & USDA/STS 2015 & FAO/WRB 2006 \\
\hline GR02 & $\begin{array}{l}\text { Typic } \\
\text { Cryumbrepts }\end{array}$ & $\begin{array}{l}\text { Dystric } \\
\text { Cambisol }\end{array}$ & SE01 & $\begin{array}{l}\text { Calcic } \\
\text { Haploxeralfs }\end{array}$ & $\begin{array}{l}\text { Calcic } \\
\text { Luvisol }\end{array}$ \\
\hline GR03 & Xerorthents & $\begin{array}{l}\text { Calcaric } \\
\text { Regosol }\end{array}$ & SE02 & $\begin{array}{l}\text { Typic } \\
\text { Rhodoxeralfs }\end{array}$ & $\begin{array}{l}\text { Rhodic } \\
\text { Luvisol }\end{array}$ \\
\hline GR04 & $\begin{array}{l}\text { Lithic } \\
\text { Xeroshrepts }\end{array}$ & $\begin{array}{l}\text { Lithic } \\
\text { Leptosol }\end{array}$ & SE03 & $\begin{array}{l}\text { Typic } \\
\text { Chromoxererts }\end{array}$ & $\begin{array}{l}\text { Calcic } \\
\text { Vertisol }\end{array}$ \\
\hline GR05 & Rhodoxeralfs & $\begin{array}{l}\text { Calcic } \\
\text { Luvisol }\end{array}$ & SE04 & $\begin{array}{l}\text { Entic } \\
\text { Haploxerolls }\end{array}$ & $\begin{array}{l}\text { Haplic } \\
\text { Phaeozem }\end{array}$ \\
\hline GR06 & Xerorthents & $\begin{array}{l}\text { Calcaric } \\
\text { Regosol }\end{array}$ & SE05 & $\begin{array}{l}\text { Salorthidic } \\
\text { Fluvaquents }\end{array}$ & $\begin{array}{l}\text { Sodic } \\
\text { Solonchak }\end{array}$ \\
\hline GR07 & $\begin{array}{l}\text { Calcixerollic } \\
\text { Xerochrepts }\end{array}$ & $\begin{array}{l}\text { Calcic } \\
\text { Cambisol }\end{array}$ & SE06 & Palexerults & $\begin{array}{l}\text { Distric } \\
\text { Nitisol }\end{array}$ \\
\hline GR08 & $\begin{array}{l}\text { Rendollic } \\
\text { Xerorthents }\end{array}$ & $\begin{array}{l}\text { Calcaric } \\
\text { Regosol }\end{array}$ & SE07 & Chromoxererts & $\begin{array}{l}\text { Pellic } \\
\text { Vertisol }\end{array}$ \\
\hline GR09 & $\begin{array}{l}\text { Entic } \\
\text { Chromoxererts }\end{array}$ & $\begin{array}{l}\text { Chromic } \\
\text { Vertisol }\end{array}$ & SE08 & $\begin{array}{l}\text { Aquic } \\
\text { Haploxeralfs }\end{array}$ & $\begin{array}{l}\text { Ferric } \\
\text { Luvisol }\end{array}$ \\
\hline GR10 & $\begin{array}{l}\text { Calcic } \\
\text { Rhodolxeralfs }\end{array}$ & $\begin{array}{l}\text { Calcic } \\
\text { Luvisol }\end{array}$ & SE09 & $\begin{array}{l}\text { Typic } \\
\text { Xerofluvents }\end{array}$ & $\begin{array}{l}\text { Calcaric } \\
\text { Fluvisol }\end{array}$ \\
\hline
\end{tabular}

